IZA DP No. 7582

Remittances and Occupational Outcomes of the Household Members Left-Behind

Matloob Piracha

Teresa Randazzo

Florin Vadean

August 2013 


\title{
Remittances and Occupational Outcomes of the Household Members Left-Behind
}

\author{
Matloob Piracha \\ University of Kent \\ and IZA
}

Teresa Randazzo

University of Kent

Florin Vadean

University of Kent

\section{Discussion Paper No. 7582 \\ August 2013}

IZA

\author{
P.O. Box 7240 \\ 53072 Bonn \\ Germany
}

\author{
Phone: +49-228-3894-0 \\ Fax: +49-228-3894-180 \\ E-mail: iza@iza.org
}

\begin{abstract}
Any opinions expressed here are those of the author(s) and not those of IZA. Research published in this series may include views on policy, but the institute itself takes no institutional policy positions. The IZA research network is committed to the IZA Guiding Principles of Research Integrity.

The Institute for the Study of Labor (IZA) in Bonn is a local and virtual international research center and a place of communication between science, politics and business. IZA is an independent nonprofit organization supported by Deutsche Post Foundation. The center is associated with the University of Bonn and offers a stimulating research environment through its international network, workshops and conferences, data service, project support, research visits and doctoral program. IZA engages in (i) original and internationally competitive research in all fields of labor economics, (ii) development of policy concepts, and (iii) dissemination of research results and concepts to the interested public.
\end{abstract}

IZA Discussion Papers often represent preliminary work and are circulated to encourage discussion. Citation of such a paper should account for its provisional character. A revised version may be available directly from the author. 
IZA Discussion Paper No. 7582

August 2013

\section{ABSTRACT \\ Remittances and Occupational Outcomes of the Household Members Left-Behind}

This paper analyses the role of remittances and migration on the occupational outcomes of the household members left behind in Tajikistan. Using the control function approach, we show that, contrary to some existing evidence, there is no "dependency" effect of remittances. Our results show that remittances received by households in Tajikistan have an important contribution to generate employment opportunities for those remaining in the country. This is likely to have a positive impact on the growth and development in Tajikistan. The results obtained are likely to have policy implications for other developing countries as well.

JEL Classification: F22, J24

Keywords: remittances, occupational choice, control function approach, Tajikistan

Corresponding author:

Matloob Piracha

Department of Economics

University of Kent

Canterbury, Kent CT2 7NP

United Kingdom

E-mail: M.E.Piracha@kent.ac.uk 


\section{Introduction}

Many empirical studies have underlined the interrelationship between migration and development. One stream of research in this area is focused on occupational choices, especially the possible entrepreneurial tendencies, of return migrants. Given the financial constraints in the country of origin, which hinder the development of entrepreneurial activities, remittances and repatriated savings are a way to finance new projects (Mesnard 2004; Ilahi 2002; Dustmann and Kirchkamp 2002). Furthermore, compared to non-migrants, return migrants or those living in households with return migrants are more likely to be selfemployed and, thus, help create employment opportunities in the home country's labour market with positive consequences for growth and development (Giulietti et al. 2013; Demurger and Xu 2011; Piracha and Vadean 2010).

While there are a number of papers that look at remittances, return migration and occupational choice, the effect of remittances on the occupational choices of the non-migrant household members has received less attention. ${ }^{1}$ Nevertheless, there are a number of ways in which migration and remittances could affect those remaining in the home country. ${ }^{2}$ For instance, since remittances from migrants usually take place under conditions of asymmetric information, there could be a possible moral hazard problem in which the relative in the home country exerts minimal effort, which is not observable by the migrant (see Chami et al. 2003). This could, in the extreme, mean that the relative remaining in the country of origin enjoys leisure at the expense of the migrant and chooses not to work at all. On the upside, remittances can be used by household members in entrepreneurial activities and, thus, generate wealth and employment, especially in the presence of credit constraints (see Woodruff and Zenteno 2007).

Acosta (2007) examines the effect of either 'access to remittances' and 'living in a migrant household' on labour force participation, hours worked and occupational choice of those left behind. He uses a nationally representative household survey from El Salvador and implements an instrumental variable approach to correct for bias due to endogeneity of remittances and migration variables. He finds gender differences in the use of remittances across households: access to remittances produces a disincentive effect on participation and number of hours worked for women, but not for men. Regarding occupational choice, Acosta

\footnotetext{
${ }^{1}$ A slightly related literature covers the impact of remittances on the labour market participation of those left behind (Kim 2007; Funkhouser 2006). Justino and Shemyakina (2010) conduct such an analysis for Tajikistan and find that adults in remittance receiving households are less likely to participate in the labour market and supply fewer working hours; the effect being stronger for men.

${ }^{2}$ For a review of the related literature, see Antman (2013).
} 
shows that remittances increase the probability to work on own-account among men, while recipient females are more likely to be microenterprise owners. Across gender the effect is much stronger in rural areas. The results suggest that international transfers can help boost business and overcome liquidity constraints, in particular in underdeveloped areas. The hypothesis that remittances create access to self-employment activities in the presence of lack of capital is supported, for example, by empirical findings for Pakistan (Adams 1998), Thailand (Paulson and Townsend 2004), Mexico (Woodruff and Zenteno 2007), and the Philippines (Yang 2008).

With the different possible effects of remittances on the remaining household, it is important to understand their role on development through the occupational decisions of those left behind. ${ }^{3}$ We analyse such an impact in Tajikistan, a country experiencing a significant outflow of temporary labour migration due to poor living conditions and lack of jobs. We use the 2007 Tajikistan Living Standards Survey (TLSS) and consider four possible occupational outcomes: a) not working, b) working on a household farm, c) working in a household business, and d) wage employment. Given that agriculture accounts for about 20 per cent of Tajikistan's GDP and employs over 60 per cent of the labour force (see European Training Foundation 2010), we explicitly distinguish between working in either a household farm or non-farm business in order to determine whether access to remittances allows households to engage in riskier non-farm investments.

We find that for men remittances have a negative impact on working as wage employee. Moreover, after controlling for endogeneity, the positive effect of receiving remittances on not working disappears, while the effect on working in one's own household business becomes positive and significant. This reveals a link between remittances and household investments in job creating activities, with a potentially positive effect on economic development. For women, however, we find no significant impact of remittances on occupational outcomes. This is most probably due to the fact that women occupation outcomes in Tajikistan's society are mainly determined by culture and tradition. The argument is confirmed by a decomposition analysis, showing that the differences in predicted probabilities between men and women are mainly due to 'treatment' (i.e., belonging to the gender group) than to 'endowment' (i.e., gender differences in characteristics).

\footnotetext{
${ }^{3}$ Banerji and Newman (1993) argue that "there are several ways in which the dynamics of occupational choice influence the process of development. Most obvious among them is the effect on the distribution of income and wealth. Insofar distribution can affect saving, investment, risk bearing, fertility and the composition of demand and production, there is a clear link with the economy's rate of growth and hence with development in its narrowest sense" (page 275).
} 
The remainder of the paper is organized as follows. Section 2 provides some background on the migration and labour market situation in Tajikistan. Section 3 presents the descriptive statistics while Section 4 describes the empirical approach. Results are discussed in Section 5 and the concluding remarks appear in the last section.

\section{Labour market and migration in Tajikistan}

Tajikistan is classified as one of the poorest countries in the world. Instability after the collapse of the Soviet Union contributed to the slow down of the development process with a significant consequence on the standard of living. The 1992-1998 civil war compromised the poor physical infrastructure and destroyed much of human and social capitals of this already beleaguered economy.

Despite the economic reforms in the last decade that have allowed the country to achieve substantial welfare improvements, ${ }^{4}$ poverty is still a threat for majority of Tajiks. The World Bank (2009) reports that 41 per cent of the population was living below the poverty line at the end of 2007 . The most affected by poverty are the rural areas that host about 75 per cent of the population (World Bank 2009). The lack of employment opportunities is a pressing issue in Tajikistan as the labour market has failed to respond to the rapid population growth. According to the official statistics, the labour force participation rate was 51.7 per cent $(2,201,000$ people) in 2007 and is much lower among females and in the urban areas (European Training Foundation 2010). The main sector of employment is agriculture whereas the industrial production is weak and concentrated in few regional centres.

Estimates of the unemployment level vary with respect to the source of data: according to the State Statistics Committee the unemployment rate was reasonably constant between 2000 and 2007 at 2.3 per cent, estimates on the basis of the Labour Force Survey give an unemployment level of 7.4 per cent in 2004, while estimates based on the 2007 Tajikistan Living Standard Survey reveal an unemployment rate of 9.5 per cent. By themselves, those numbers are not high but it is important to note that the figures are relatively low because of labour emigration and the high rate of inactivity in the labour market (about 48.3 per cent). Overall, the unemployment rate is much higher in urban than rural areas and women are more affected than men. Young people are the category suffering most from the lack of jobs and migration represents a relief/safety valve to this problem.

\footnotetext{
${ }^{4}$ The average monthly per capita income increased in real terms from 119 somoni (about USD 40) in 2003 to 150 somoni (about USD 43) in 2007.
} 
The migration trends in Tajikistan reflect the history of the country and one can identify different phases. The early 1990s were characterized by a refugee flow due to political instability and the civil war (1992-1997), which led to a significant change in the ethnic composition of the population. The census conducted in Tajikistan in 2000 revealed that between 1989 and 2000 the country became more Tajik, as their share in the population increased from 62.3 to 79.9 per cent, while the presence of other ethnic groups decreased substantially (Erlich 2006). The most important outflow concerned the Russians as the civil war made it dangerous for them to stay and many of them returned to Russia or moved to other ex- Soviet Republics. Also, many ethnic Turkmen, Kyrgyz and Uzbek fled the country during the civil war and the majority of them did not return or reclassified themselves as ethnic Arabs or Tajiks.

The late 1990s and 2000s saw an increase in labour migration to an unprecedented scale. The International Labour Organisation (2010) reports that an estimated 500,000 to 800,000 Tajik nationals (or about 10 per cent of the total population) have left the country to work abroad, the majority (over 95 per cent) to Russia. Most migration flows are temporary/seasonal in the lower skilled and informal sectors in agriculture, construction, trade and communal services. Migrants are predominantly young men from rural areas, many of them with completed secondary or vocational education. ${ }^{5}$ The majority of migrants are married, but they only seldom migrate with their family, as their wages are low and insufficient to meet family needs in the host country. Nevertheless, their incomes are sufficient for sustaining the family in Tajikistan, where the cost of living is significantly lower.

Migrants' remittances represent an important source of income for many households in Tajikistan. For a considerable number of Tajiks the income abroad is the only way to provide for the basic needs of their families. Migration, therefore, can be seen as a survival strategy for dealing with poverty. According to the State Statistical Committee, only 30 per cent of households with at least one member abroad consider themselves poor compared to 65 per cent of the overall population (Olimova and Bosc 2003). According to Riester (2012), remittances amounted to $\$ 2.5$ billion in 2008 and represented 49.6 per cent of the country's GDP.

\footnotetext{
${ }^{5}$ In 2005, among those who travelled abroad to earn a living for the first time, 88 per cent were younger than 30 (International Organization for Migration, 2006).
} 


\section{Data}

We study the impact of remittances and migration on the individual's activity choice decision using cross-sectional data from the Tajikistan Living Standards Survey 2007 (henceforth TLSS 2007). The data has been collected in two stages from September to November 2007 involving the National Statistical Committee of Tajikistan, the World Bank and the United Nations Children's Fund. The survey, designed mainly to allow for a reliable assessment of poverty and living standards in Tajikistan, considers different aspects of individual and household characteristics and covers a wide range of topics such as migration, employment, income, expenditure, health and nutritional status, and agriculture. The goal of the survey was to stimulate the wider use of household data for the implementation of policies aimed to reduce poverty in a country in which a consistent part of the population is not able to meet its basic need (World Bank 2009). The total sample, representative at the national level, contains 4,860 households.

The working population in Tajikistan (15 to 62 for men and 15 to 57 for women) consists of 4.2 million individuals though only half of them are part of the labour force, the other half being inactive (World Bank 2009). The low labour market participation in Tajikistan is captured by the survey data: about 50 per cent of the sampled adults are outside the labour force. Housewife is the category that dominates the non-labour market participant group (47 per cent) and further 26 per cent report to be students. The rest of the inactive individuals are either retired, discouraged in finding a job or working seasonally.

For the purpose of our study we restrict our sample to the working age adults, i.e., 15 to 62 for males and 15 to 57 for females. After dropping handicapped, housewives, students, individuals in retirement and military service as well as observations with missing values for the variables of interest, we end up with 9,366 individuals: 5,909 males and 3,457 females.

Under the hypothesis that remittances can affect the labour market decisions of those left behind, we consider four possible outcomes: not working; working on a household farm; working in a household business; and wage employment (i.e., working for a non-family business). The 'not working' category includes those who at the time of the survey were either unemployed, waiting for a recall by the employer, discouraged because of not finding a job, or waiting for a busy season. We consider separately those working in agriculture and any other type of business within the household because of the possibility of a different strategy behind the two categories: having access to remittances could allow households to take more risk and diversify into non-farm business. 
The analysis is focused exclusively on international remittances, defined as monetary and in kind transfers received by the household from abroad during the past 12 months. The information on remittances is collected in two different sections of the questionnaire. The first section contains questions on household members being abroad at the time of survey, including the amount of remittances received from them only. The second includes questions about transfers received from all sources including relatives, friends and institutions based in or outside Tajikistan, but the amount of remittances is reported only for those received from abroad. (Amounts of internal remittances are not fully reported in the survey).

Descriptive statistics in Table 1 show that about 15 per cent of working age men (aged 15 to 62) and about 19 per cent working age women (15 to 57) live in households receiving remittances. The average amount of yearly remittances received by the receiving households is about TJS 2,835 (or USD 819) and TJS 3,022 (or USD 872) for men and women, respectively. ${ }^{6}$

A larger share of men living in remittance receiving households is secondary educated (+4 percentage points) but a smaller share is tertiary educated ( -6 percentage points) compared to those living in non-receiving households. Better educated men are more likely to face better opportunities in the labour market in terms of jobs and wages and, therefore, their families are less dependent on remittances. As expected, a larger share of the men living in remittance receiving households is ethnic Tajik (86.6 vs. 77.7 per cent) and lives in rural areas (78.5 vs. 69.6 per cent). As discussed in Section 2, many Tajik nationals of other ethnicities fled the country during the 1990's civil war and never returned; most of them eventually lost all contacts with their former home country. On the other hand, in the aftermath of the civil war, ethnic Tajiks predominantly from less developed rural areas started to migrate to Commonwealth of Independent States (CIS) in search of job opportunities.

Differences exist also with respect to region of origin. Those from the Region of Republican Subordination and Gorno-Badakhshan are strongly represented in the labour migrant group (Olimova and Bosc 2003), which is why there is a higher share of individuals in remittance receiving households living in those regions $(+5.7$ and +12.9 percentage points,

\footnotetext{
${ }^{6}$ The average amount of annual remittances per household (including receiving and non-receiving households), estimated using TLSS2007, is about USD 139. This average amount is significantly lower compared to a simple estimate based on the total amount of international remittances reported by the National Bank of Tajikistan for 2007 (USD 1.8 billion) and the total number of households reported by the 2010 census ( 1.2 million), giving an amount of yearly remittances received by the average Tajik household of about USD 1,500. This reveals that the amount of remittances in the TLSS2007 is underreported by a factor of about 10 .
} 
respectively). With respect to the household structure, those receiving remittances seem to have on average a lower number of children and elderly. This could be due to the fact that the more recent emigration cohorts consisted of relatively young men (below the age of 30), who are more likely to have fewer children and perhaps working age parents.

There is a very strong correlation between living in a remittance receiving household and having household members abroad: 76.9 per cent of men and 81.3 of women in remittance receiving households have a household member abroad, revealing that remittances are predominantly received from very close family members. Remittance receivers have on average one migrant abroad and live in a community with on average twice as many emigrants compared to non-receivers. Migration and remittances seem, therefore, to be an unevenly spread phenomenon, clustered at community level and with networks playing an important role.

Furthermore, we observe that a larger share of individuals living in a household receiving remittances are not working $(+8.3$ percentage points for men and +3.6 percentage point for women) and a smaller share of them are wage employees (-11.8 percentage points for men and -8.4 percentage points for women), compared to those living in a non-receiving household. The larger share of men not working could be explained by the fact that some of them are temporary/circular migrants and mainly work abroad and enjoy leisure while at home. In the case of women, the extra income from abroad could possibly allow them to dedicate more time for parenting. Nevertheless, women seem also to often take up duties otherwise fulfilled by the absent men, which could explain the larger share of women in remittance receiving households ( +3.6 percentage points) working on a household farm.

\section{Empirical approach}

We use a random utility model to assess the labour market decisions of individuals. We assume that an individual chooses from four mutually exclusive alternatives: not working, working on a household farm, working in a household business, and working as wage employee. The utility that individual $n$ obtains from alternative $j$ is given by:

$$
U_{n j}=V\left(\operatorname{rem}_{n}, x_{n}, \beta_{j}\right)+\varepsilon_{n j}
$$

where $V_{n j}$ is the utility that depends on observed factors (i.e., representative utility), rem $_{n}$ stands for the amount of remittances received by the household of individual $n, x_{n}$ is a vector 
of exogenous variables relating to individual, household and regional characteristics and $\varepsilon_{n j}$ is the disturbance term and captures unobserved factors that affect the utility.

Assuming that $\varepsilon_{n j}$ is random, the probability that individual $n$ chooses alternative $j$ is:

$$
\begin{aligned}
& \mathrm{P}_{n j}=\operatorname{Prob}\left(\mathrm{U}_{n j}>\mathrm{U}_{n i} \forall j \neq i\right) \\
& =\operatorname{Prob}\left(\mathrm{V}_{n j}+\varepsilon_{n j}>\mathrm{V}_{n i}+\varepsilon_{n i} \forall j \neq i\right) \\
& =\operatorname{Prob}\left(\varepsilon_{n i}-\varepsilon_{n j}<\mathrm{V}_{n j}-\mathrm{V}_{n i}+\forall j \neq i\right)
\end{aligned}
$$

The amount of remittances received by a household $\left(\right.$ rem $\left._{n}\right)$ is likely, however, to be endogenous. For example, less risk averse households are more likely to send migrants abroad who then send remittances home and the level of risk aversion is also likely to influence the decision to start a business or not. Consequently, the unobserved term $\varepsilon_{n j}$ is not independent of rem $_{n}$ as required for standard estimation.

One solution for dealing with endogeneity in this non-linear setting is to apply the control function approach (see Train 2009). Let the amount of remittances be expressed as a function of observed instruments and unobserved factors:

$$
\operatorname{rem}_{n}=W\left(z_{n}, x_{n}, \gamma\right)+\mu_{n}
$$

where $\varepsilon_{n j}$ (from equation 1) and $\mu_{n}$ are independent of $z_{n}$ and $x_{n}$, but $\varepsilon_{n j}$ and $\mu_{n}$ are correlated. The vector $z_{n}$ contains a set of instruments that are correlated with rem $_{n}$ but not enter directly the utility function $\left(U_{n j}\right)$. Following Petrin and Train (2010), $\varepsilon_{n j}$ is decomposed into a part that can be explained by a general function of $\mu_{n}$ and a residual:

$$
\varepsilon_{n j}=C F\left(\mu_{n}, \lambda\right)+\tilde{\varepsilon}_{n j}
$$

where $C F\left(\mu_{n}, \lambda\right)$ denotes the control function with parameters $\lambda$. We specify the control function as linear in $\mu_{n}$ (i.e., $C F\left(\mu_{n}, \lambda\right)=\lambda \mu_{n}$ ), giving utility the following form:

$$
U_{n j}=V\left(\operatorname{rem}_{n}, x_{n}, \beta_{j}\right)+\lambda \mu_{n}+\tilde{\varepsilon}_{n j}
$$

The choice probabilities are derived from the conditional distribution of the residual $\tilde{\varepsilon}_{n j}$. 
Denoting the conditional distribution of $\tilde{\varepsilon}_{n j}$ by $g\left(\tilde{\varepsilon}_{n j} \mid \mu_{n}\right)$ and the distribution of $\beta_{j}$ by $f\left(\beta_{j} \mid \theta\right)$, the choice probability is:

$$
\begin{aligned}
& \mathrm{P}_{n j}=\operatorname{Prob}\left(\mathrm{U}_{n j}>\mathrm{U}_{n i} \forall j \neq i\right) \\
& =\iint I\left(\mathrm{~V}_{n j}+\lambda \mu_{n}+\tilde{\varepsilon}_{n j}>\mathrm{V}_{n i}+\lambda \mu_{n}+\tilde{\varepsilon}_{n i} \forall j \neq i\right) g\left(\tilde{\varepsilon}_{n j} \mid \mu_{n}\right) f\left(\beta_{j} \mid \theta\right) d \tilde{\varepsilon} d \beta
\end{aligned}
$$

This is a standard choice model, with the control function entering as an extra explanatory variable. The model is estimated in two steps. First, equation (3) is estimated by OLS with the endogenous rem $_{n}$ variable as the dependent variable and with exogenous instruments (i.e., $z_{n}$ and $x_{n}$ ) as explanatory variables. Using the estimated parameters $\hat{\gamma}$ from the OLS regression the residual is calculated as $\hat{\mu}_{n}=\operatorname{rem}_{n}-W\left(z_{n}, x_{n}, \hat{\gamma}\right)$. In the second step, the choice model is estimated using multinomial probit with $\hat{\mu}_{n}$ as additional covariate.

We use two instruments $\left(z_{n}\right)$ to identify the model: being an ethnic Tajik and the number of migrants aged 16 to 64 in the local community in 2004. Ethnic Tajiks dominate labour migration from Tajikistan and there is also a larger share of ethnic Tajiks in the population group living in remittance receiving households (see Erlich 2006 and Table 1). On the other hand, as discussed in Section 2, individuals of other ethnic minorities (i.e., Russians, Tatars, Uzbeks, etc.) left the country as refugees during the 1990s civil war, often with their entire families and have never returned. Therefore, living in an ethnic Tajik household increases the likelihood of receiving remittances but should not affect household members occupational choice. The main reason for using the second instrument is that migrant networks facilitate current migration by providing communities with information about opportunities in foreign labour markets and consequently have a positive effect on current remittance flows as well. Migration history and community migrant networks have been widely used as instrumental variables in other empirical studies as well (see Justino and Shemyakina 2012; Demurger and Xu 2011; Acosta 2007).

As monetary variables in survey data collection are often underreported (see Mayer et al. 2009 and Section 3), we replace the amount of remittances with the "number of household members a migrant" $\left(n m i g_{n}\right)$ to check for the robustness of the results. ${ }^{7}$ The empirical strategy is similar, except that, given the count nature of the $n m i g_{n}$ variable, we estimate equation (3) by a generalised linear model (GLM). Using the parameters from the GLM

\footnotetext{
${ }^{7}$ A household sending more migrants abroad is likely to receive more remittances.
} 
estimation, we obtain the fitted values for the number of household members who are a migrant $\left(n \widehat{m l} g_{n}\right)$ and use them to calculate the deviance residual:

$$
\hat{d}_{n}=\operatorname{sgn}\left(n m i g_{n}-n \widehat{m l} g_{n}\right) \sqrt{2\left(n m i g_{n} \log \left(\frac{n m i g_{n}}{n \widehat{m \imath} g_{n}}\right)-\left(n m i g_{n}-n \widehat{m l} g_{n}\right)\right)}
$$

The choice model is then estimated using multinomial probit with $\hat{d}_{n}$ as additional covariate.

In addition, it is important to explore differences in occupational outcomes between gender groups. This can be done by computing the predicted probability differentials between the two groups and by assigning any difference to 'treatment' (i.e. difference due to coefficients) and 'endowment' (i.e. difference due to characteristics) components. The decomposition is relatively straightforward in the linear regression context (see Oaxaca 1973). The approach was extended by Gomulka and Stern (1990) for binary dependent variables, Lichfield and Reilly (2009) for bivariate probit and Bauer and Sinning (2010) for tobit models. We follow the approach outlined by Gill (1989), which is applicable to multinomial logit models.

The sample average predicted probability for attaining occupation $j$ in the case of men can be expressed as:

$$
\frac{1}{N_{M}} \sum_{n=1}^{N_{M}} \frac{e^{\hat{\beta}_{j M} r e m_{n M} x_{n M \mu_{n M}}}}{\sum_{k=N W, F F, F B, W A} e^{\hat{\beta}_{j M}{ }^{r e m_{n M} x_{n M} \mu_{n M}}}}
$$

where $N_{M}$ denotes the sample size of men and $\left(\hat{\beta}_{j M}\right)$ denote the coefficients obtained for the occupational outcome $j$ from estimating the choice equation by multinomial logit for the men subsample.

The corresponding sample average predicted probability for attaining occupation $j$ in the case of women is expressed as:

$$
\frac{1}{N_{F}} \sum_{n=1}^{N_{F}} \frac{e^{\hat{\beta}_{j F} r e m_{n F} x_{n F} \mu_{n F}}}{\sum_{k=N W, F F, F B, W A} e^{\hat{\beta}_{j F} r e m_{n F} x_{n F} \mu_{n F}}}
$$


where $N_{F}$ denotes the sample size of women and $\left(\hat{\beta}_{j F}\right)$ denotes the coefficients obtained for the occupational outcome $j$ from estimating the choice equation by multinomial logit for the women subsample.

Two counterfactual predicted probabilities are introduced for the decomposition analysis. The first provides the sample average predicted probability for men if subjected to women coefficient structure (i.e., the men's predicted probability of attaining occupation $j$ if they would be women):

$$
\frac{1}{N_{M}} \sum_{n=1}^{N_{F}} \frac{e^{\hat{\beta}_{j F} r e m_{n M} x_{n M \mu_{n M}}}}{\sum_{k=N W, F F, F B, W A} e^{\hat{\beta}_{j F} r e m_{n M} x_{n M} \mu_{n M}}}
$$

The second counterfactual is constructed for the women subsample and provides the sample average predicted probability for women if confronted by the men coefficient structure (i.e. the women's predicted probability of attaining occupation $j$ had they been men):

$$
\frac{1}{N_{F}} \sum_{n=1}^{N_{F}} \frac{e^{\hat{\beta}_{j M} r e m_{n F} x_{n F} \mu_{n F}}}{\sum_{k=N W, F F, F B, W A} e^{\hat{\beta}_{j M} M^{r e m_{n F} x_{n F} \mu_{n F}}}}
$$

These four measures allow the computation of the total difference in sample average predicted probabilities between the two population groups as: (8) - (9). Using men's coefficients, the difference due to characteristics (i.e. endowment effect) can be computed by subtracting (11) from (8) and the difference due to coefficients (i.e. treatment effect) by subtracting (9) from (11). Alternatively, using women's coefficients, the endowment effect is $(10)-(9)$ and the treatment effect is (8) - (10). The approach is subject to the standard index number problem and is sensitive to which coefficients are used to weight the characteristics. A desirable approach is thus to report both estimates and assess the degree of sensitivity.

\section{Results}

We run a multinomial probit estimation as a baseline for the analysis of the effect of remittances on occupational outcomes. The estimated marginal effects for men (Table 2) are in line with results from previous studies (Giulietti et al. 2013; Mendola and Carletto 2012; Demurger and $\mathrm{Xu}$ 2011; Piracha and Vadean 2010). ${ }^{8}$ Everything else equal, we find a

\footnotetext{
${ }^{8}$ We ran estimations for women as well, but we do not find any significant effect of remittances on their occupational outcome so we do not report them. Results are available upon request.
} 
positive relationship between age and either working as a wage employee or in a household business. The ability of being self-employed increases with age because individuals accumulate both financial and human capital (see also Demurger and $\mathrm{Xu}, 2011$ ). Conversely, not working is negatively related to age, confirming the fact that young adults in Tajikistan are the group mostly affected by lack of employment opportunities (see International Organization for Migration, 2006).

Education plays an important role in the occupational outcome as well. Ceteris paribus, tertiary education strongly increases the probability of working as a wage employee (26.2 per cent) and decreases the probability of all other alternatives: working in a family business (-12.9 per cent), not working (-9.1 per cent), and working on a family farm (-4.2 per cent). Secondary education has a similar effect on occupation, but to a smaller extent: it increases the probability of wage employment by 6.5 per cent and decreases the probability of working on a household farm by 3.9 per cent. These results are in line with findings from previous studies on occupational outcomes in developing countries. Piracha and Vadean (2010) find that better educated individuals in the Albanian labour market are less likely not to work or work on own account compared to being wage employees. Similarly, Mendola and Carletto (2012) find that years of education increase the probability of working as wage employee and decrease the probability of being self-employed. Ilahi (1999), using data from Pakistan, also finds that unskilled workers are often left outside the labor market and choose to engage in own account activities that do not require labor market skills, for example, small trade or workshops. Another possible explanation for these results is that employment in the family (farming or non-farming) business might be used by the less skilled as a safety net or as a flexible employment opportunity between migration trips.

Married men are more likely to work in a household business (+3.9 per cent) or as wage employees (+4.3 per cent) and less likely not to work (-9.6\%), revealing that family duties are an important incentive for taking up employment (see also Giulietti et al. 2013 and Demurger and Xu 2011). Nevertheless, having sufficient income to support a family is often a prerequisite for marriage in the case of men. The presence of children in the household seems, however, to put further pressure on adult men to make a positive contribution to the family income. At mean, the presence of an additional child (aged 14 or less) in the household decreases the likelihood of men not to work (-1.1 per cent) and increases the likelihood to work in the household non-farm business (+1.6 per cent).

Working on a household farm seems not to be explained by marital status or household structure. A possible explanation for it is that the likelihood to choose agriculture 
activity depends rather on place of residence and access to agricultural land. In fact, living in a rural location increases the probability of working on a household farm by almost 7 per cent.

The amount of remittances received by the household is our main covariate of interest. As in previous studies that have not controlled for the endogeneity of receiving remittances, we find a negative impact of the amount of remittances received by the household on labour market participation. Everything else equal, a one per cent increase in remittances received by the household increases the probability of not working by 0.6 per cent, while it decreases the probability of working as wage employee by 1.0 per cent. As discussed in Section 4 this result might, however, be biased.

We apply a control function approach in order to correct for the endogeneity. As described in Section 4, the two instruments selected to identify the model are: a) the number of migrants in the local community (i.e., as a proxy for migrants' networks) and b) a dummy for being ethnic Tajik. To test for the validity of the instruments, we first introduce them as explanatory variables in the multinomial probit occupational choice estimations and find both not to be correlated with the occupational outcomes: the combined F-test of the coefficients in all four occupation equations is 4.05 for the number of migrants in the community and 6.29 for being ethnic Tajik. Moreover, the instruments are strong: the F-test of the joint significance of the instruments' coefficients from the remittances OLS estimation is 21.25 and thus higher than the Stock and Yogo (2005) 11.59 critical value, given one endogenous regressor, two instrumental variables, and a 15 per cent maximum size of a 5 per cent Wald test.

The first column of Table 3 reports the first step of the control function approach that is an OLS estimation of the log of the amount of remittances received. As expected from the results of the F-test, the two excluded instruments strongly determine the amount of transfers from abroad. Ceteris paribus, one more emigrant in the community migrant network in 2004 increases the amount of household remittances received at time of survey by 27.5 per cent. This is consistent with the findings of Acosta (2007) who argues that the social network abroad facilitates the migration process and influences significantly the likelihood of being a recipient family. Moreover, as discussed earlier, ethnic Tajiks dominate Tajikistan's labour migration. It is, therefore, not surprising that, everything else equal, ethnic Tajiks live in households receiving on average 31.2 per cent more remittances. The amount of transfers received is negatively affected by age ( -10.3 per cent) and having tertiary education $(-35.3$ per cent). As better-educated individuals are likely to have similarly educated close relatives 
(i.e., spouse, children, and parents; see Bruze 2011 and Holmlund et al. 2011), members of these households would have better employment opportunities in the Tajik labour market and be less dependent on labour migration and remittances.

The last four columns of Table 3 present the marginal effects after a multinomial probit of occupational choice with the OLS residuals from the first stage as additional covariate. The significant marginal effects for the OLS residual confirm the presence of an endogeneity bias. Therefore, the control function approach is to be preferred to the simple multinomial probit estimation. We find that the effect of remittances on not working disappears after controlling for endogeneity. On the other hand, the negative effect on working as wage employee becomes stronger, from -1.0 per cent to -5.2 per cent: ceteris paribus, a one per cent increase in the amount of remittances received decreases the probability of wage employment by -5.2 per cent. Moreover, the impact on working in a household business becomes positive and significant: a one per cent increase in the amount of remittances received increases the likelihood of employment in the household business by 4.0 per cent. So, contrary to the findings of Justino and Shemyakina (2012), we find no "dependency" effect of remittances on those left behind. Our results rather show that remittances received by households in Tajikistan, besides being used for covering daily needs, have an important contribution to generate employment opportunities for the family members left behind.

In Section 3 we estimated that the amount of remittances received is underreported in the TLSS2007 by a factor of about 10. In order to check for the robustness of the results presented above, we follow an approach used by Justino and Shemyakina (2012) and replace the amount of remittances with the number of migrants in the household. The marginal effects of the baseline multinomial probit model in Table 4 are quite similar to the one with the amount of remittances as covariate of interest (Table 2). Everything else equal, one more household migrant has a positive effect on not working and a negative effect on wage employment. Once again, after controlling for endogeneity (Table 5), ${ }^{9}$ we find that the number of household members who are a migrant has no significant effect on labour market participation, but it increases the probability of working in a family business and decreases the probability of wage employment. Those results are consistent with the previous

\footnotetext{
${ }^{9}$ The number of migrants in the local community and the dummy for being ethnic Tajik are again valid and strong instruments. In the multinomial probit occupational choice estimation the combined F-test of the coefficients in all four occupation equations is 3.84 for the number of migrants in the community and 6.35 for being ethnic Tajik. The F-test of joint significance of the instruments coefficients from the number of migrants GLM estimation is 57.18 and thus higher than the Stock and Yogo (2005) critical value.
} 
estimations using the amount of remittances as explanatory variable, with the exception that number of household migrants is positively related to working on own household farm as well. A possible explanation for it is that with respect to farming, absent household members eventually have to be replaced in their duties by the adults left behind.

The difference in predicted probabilities of occupational outcomes between men and women (Table 6$)$ shows that men are more likely not to work (+6.9 percentage points) or be wage employees $(+1.5$ percentage points $)$ and less likely to work on a household farm (-7.9 percentage points). These differences are almost certainly the result of men being predominately from rural areas who are more likely to be engaged in international labour migration or 'preparing' for migration. ${ }^{10}$ The left behind women, on the other hand, have to take over duties of the absent men.

The decomposition analysis reveals that gender differentials with respect to characteristics are mostly unimportant and observed gender occupational outcome differences are mostly due to the 'treatment' effect. The gap is unlikely to change much in the near future, as these factors are strongly determined by culture and tradition. As argued by Litchfield and Reilly (2009), these factors tend to evolve in most countries at a "glacial pace". The only area where a targeted policy for the improvement of girls schooling could eventually make a difference is with regard to wage employment, as the gender gap is about 70 per cent explained by 'endowment'.

\section{Conclusions}

The aim of this paper was to explore the impact of remittances on the occupational outcomes of those left-behind. In particular, the economic activity of non-migrant household members could be positively affected if remittances are seen as an investment opportunity in the presence of credit constraint; but it could have a detrimental effect as well if the remaining relatives consider this a simple non-labour income, hence causing them to substitute work for leisure.

We assessed the role of remittances on the labour market outcome in Tajikistan using the Living Standards Survey 2007. We implemented a control function approach to address

\footnotetext{
${ }^{10}$ The government of Tajikistan is using the export of workforce as a policy for easing labour market constraints. However, since most of the migration is to Russia, knowledge of Russian is key to labour market success while abroad (International Federation for Human Rights, 2011). The government, together with some multilateral organisations has established training centres that teach Russian language as well as labour market rules and regulations migrants need to follow. Potential migrants who attend these courses are, however, less able to fulfil their domestic obligations.
} 
the issue of endogeneity of receiving remittances and found that the amount of remittances received increases the probability for men to be employed in a household business and decreases the probability of working as wage employees, while it has no effect on the occupational outcomes of women. These results withstand a robustness check, with the amount of remittances being replaced by the number of (potential) remitters.

A decomposition analysis reveals that the differences in gender occupational outcomes are mainly due to 'treatment' (i.e., belonging to the gender group) than to 'endowment' (i.e., gender differences in characteristics) and are, therefore, most probably determined by culture and tradition. Nevertheless, as about 70 per cent of the gender gap in wage employment is explained by 'endowment', a targeted policy for the improvement of girls schooling could eventually increase the employment level of future generations of Tajik women.

Migration and remittances can help the development process of local economies. However, they cannot be the only solution for financing new activities. As is often argued in the literature (see Catrinescu et al. 2009), remittances can play an important role in development only if policymakers succeed removing constraints, such as political instability, corruption, lack of business regulation, financial constraints (access and cost of finance) and lack of good infrastructure. 


\section{References}

Acosta, P. (2007). Entrepreneurship, Labour Markets, and International Remittances: Evidence from El Salvador. In: C. Özden and M. Schiff (Eds.), International Migration, Economic Development \& Policy. World Bank and Palgrave Macmillan, 141-159.

Adams, R.H. (1998). Remittances, Investment, and Rural Asset Accumulation in Pakistan. Economic Development and Cultural Change 17 (1), 155-173.

Antman, F.M. (2013). The Impact of Migration on Family Left Behind. In: A.F. Constant and K.F. Zimmermann (Eds.), International Handbook on the Economics of Migration. Edward Elgar Publishing, 293-308.

Banerji. A., Newman, A. (1993). Occupational Choice and the Process of Development. Journal of Political Economy, 101 (2), 274-298.

Bauer, T., Sinning, M. (2010). Blinder-Oxaca Decomposition for Tobit Models. Applied Economics 42 (2), 1569-75.

Bruze, G. (2011), Marriage Choices of Movie Stars: Does Spouse's Education Matter? Journal of Human Capital 5 (1), 1-28.

Catrinescu, N., Leon-Ledesma, M., Piracha, M., Quillin, B. (2009). Remittances, Institutions and Economic Growth. World Development 37 (1), 81-92.

Chami, R., Fullenkamp, C., Jahjah, S. (2005). Are Immigrant Remittance Flows a Source of Capital for Development? IMF Staff Papers 52 (1), 55-81.

Demurger, S, Xu, H. (2011). Return Migrants: The Rise of New Entrepreneurs in Rural China. World Development 39 (10), 351-372.

Dustmann, C., Kirchkamp, O. (2002). The Optimal Migration Duration and Activity Choice after Re-Migration. Journal of Development Economics 67, 351-372.

Erlich, A. (2006). Tajikistan: From Refugee Sender to Labor Exporter, Migration Policy Institute, Washington DC.

European Training Foundation (2010). Labour Market Review: Tajikistan. Luxembourg: Publications Office of the European Union.

Funkhouser, E. (2006). The Effect of Emigration on the Labour Market Outcomes of the Sender Household: A Longitudinal Approach Using Data from Nicaragua. Well-Being and Social Policy 2 (2), 5-25.

Gill, A.M. (1989). The Role of Discrimination in Determining Occupational Structure. Industrial and Labor Relations Review 42 (4), 610-23.

Giulietti, C., Wahba, J., Zimmermann, K.F. (2013). Entrepreneurship of the Left-Behind. Research in Labor Economics 37, 65-92. 
Gomulka, J. and Stern, N. (1990). The Employment of Married Women in the United Kingdom 1970-83. Economica 57 (226), 171-99.

Holmlund, H., Lindahl, M., and Plug, E. (2011). The Causal Effect of Parents' Schooling on Children's Schooling: A Comparison of Estimation Methods. Journal of Economic Literature 49 (3), 615-51.

Ilahi, N. (2002). Return Migration and Occupational Change. Review of Development Economics 3 (2), 170-186.

International Federation for Human Rights (2011). Exporting the Workforce at What Price? Tajik Migrant Workers Need Increased Protection. Tajikistan Mission Report.

International Labour Organization (2010). Migration and Development in Tajikistan Emigration, Return and Diaspora. ILO: Moscow.

International Organization for Migration (2006). Remittances and their impact to social life in Khtalon Oblast, Republic of Tajikistan. Analytical report. IOM: Dushanbe.

Justino, P., Shemyakina, O.N. (2012). Remittances and Labour Supply in Post-Conflict Tajikistan. IZA Journal of Labour and Development 1:8.

Kim, N. (2007). The Impact of Remittances on Labour Supply: The Case of Jamaica. World Bank Policy Research Working Paper 4120, Washington, DC, USA.

Litchfield, J. and Reilly, B. (2009). Modelling Migration Attempts and the Role of Gender in Albania. Economic Annals, LIV (182), 7-39.

Meyer, B.D, Wallace, K.C., Sullivan, J.C. (2009). The Under-Reporting of Transfers in Household Surveys: Its Nature and Consequences. NBER Working Paper 15181. National Bureau of Economic Research, Cambridge, USA.

Mendola, M., Carletto, G. (2012). Migration and Gender Differences in the Home Labour Market: Evidence from Albania. Labour Economics 19 (6), 870-880.

Mesnard, A. (2004). Temporary Migration and Capital Market Imperfections. Oxford Economic Papers 56 (2), 242-262.

Olimova, S., Bosc, I. (2003). Labour Migration from Tajikistan. IOM: Dushanbe.

Oaxaca, R. (1973). Male-Female Wage Differentials in Urban Labor Markets. International Economic Review 14 (3), 693-709.

Paulson, A. and Townsend, R. (2004). Entrepreneurship and Financial Constraints in Thailand. Journal of Corporate Finance 10 (2), 229-262.

Petrin, A., Train, K. (2010). A Control Function Approach to Endogeneity in Consumer Choice Models. Journal of Marketing Research XLVII, 3-13. 
Piracha, M., Vadean, F. (2010). Return Migration and Occupational Choice: Evidence from Albania. World Development 38 (8), 1141-1155.

Riester, A. (2012). Resilience of Remittances during the Global Financial Crisis and the Entrenchment of Migration. In: I. Sirkeci, J. H. Cohen, \& D. Ratha (Eds.), Migration and remittances during the global financial crisis and beyond, Washington: World Bank, 141-147.

Stock, J.H., and Yogo, M. (2005). Testing for Weak Instruments in Linear IV Regression. In: D.W. Andrews and J.H. Stock (Eds.), Identification and Inference for Econometric Models. Cambridge University Press, 80-108.

Train, K. (2009). Discrete Choice Method with Simulation. Cambridge University Press.

Woodruff, C., Zenteno, R. (2007). Migration Networks and Microenterprises in Mexico. Journal of Development Economics 82, 509-528.

World Bank (2009). Republic of Tajikistan. Poverty Assessment. Report N. 51341-TJ.

Yang, D. (2008). International Migration, Remittances and Household Investment: Evidence From Philippine Migrants' Exchange Rate Shocks. The Economic Journal 118 (April), 591630. 
Table 1: Descriptive Statistics - men, aged 15 to 62; women, aged 15 to 57

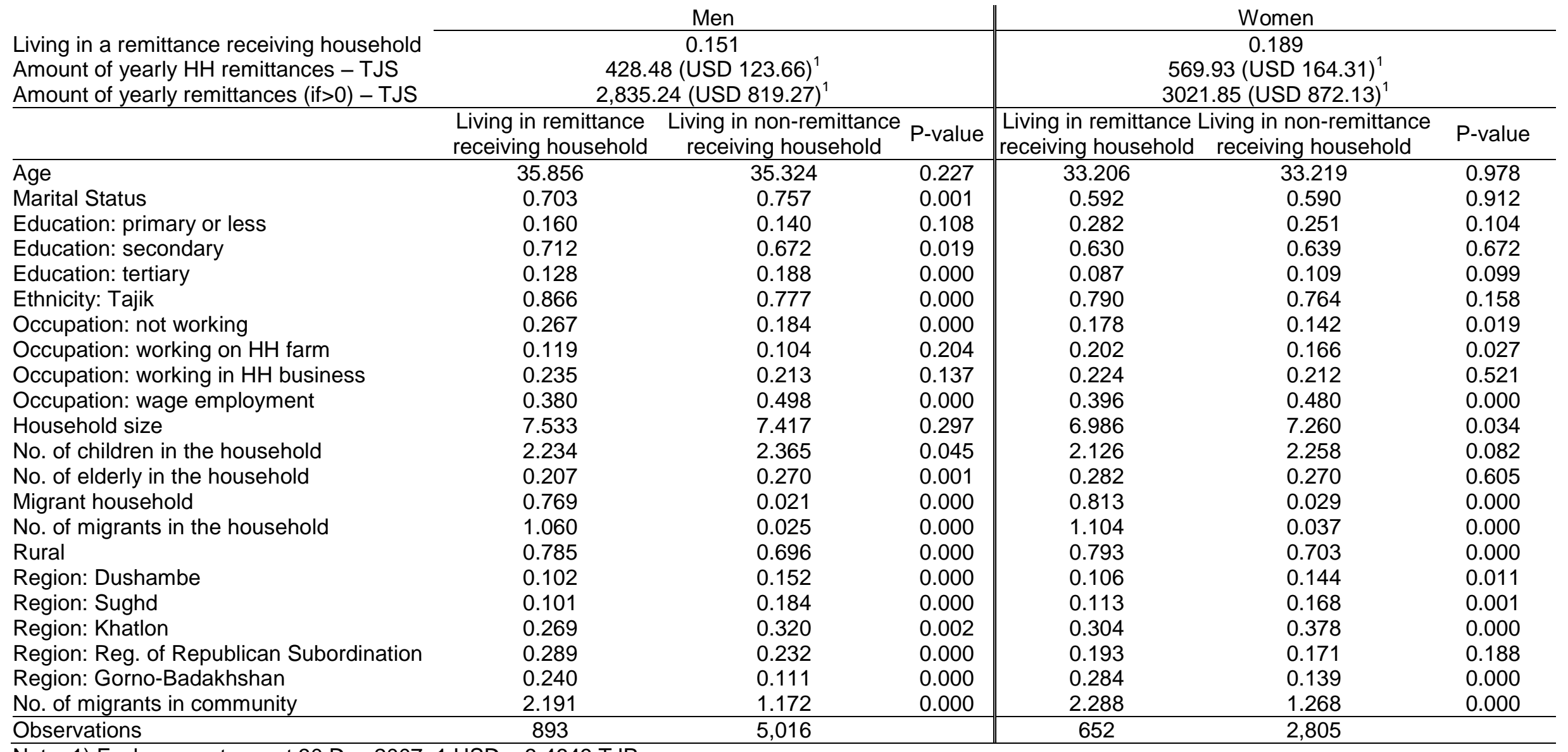

Note: 1) Exchange rate as at 30 Dec 2007: 1 USD = 3.4649 TJP. 
Table 2: Multinomial probit marginal effects - amount of remittances

\begin{tabular}{|c|c|c|c|c|}
\hline & Not working & $\begin{array}{l}\text { Working on } \\
\mathrm{HH} \text { farm }\end{array}$ & $\begin{array}{l}\text { Working in } \\
\mathrm{HH} \text { business }\end{array}$ & $\begin{array}{c}\text { Wage } \\
\text { employment }\end{array}$ \\
\hline Log of remittances & $\begin{array}{l}0.006^{\star \star *} \\
(0.002)\end{array}$ & $\begin{array}{c}0.002 \\
(0.002)\end{array}$ & $\begin{array}{c}0.003 \\
(0.002)\end{array}$ & $\begin{array}{c}-0.010^{\star \star *} \\
(0.003)\end{array}$ \\
\hline Age & $\begin{array}{c}-0.016^{* * *} \\
(0.004)\end{array}$ & $\begin{array}{l}-0.004 \\
(0.003)\end{array}$ & $\begin{array}{l}0.008^{*} \\
(0.004)\end{array}$ & $\begin{array}{l}0.013^{\star *} \\
(0.005)\end{array}$ \\
\hline Age squared x 100 & $\begin{array}{c}0.015^{\star * *} \\
(0.005)\end{array}$ & $\begin{array}{l}0.007^{*} \\
(0.003)\end{array}$ & $\begin{array}{l}-0.010^{*} \\
(0.006)\end{array}$ & $\begin{array}{l}-0.012^{*} \\
(0.006)\end{array}$ \\
\hline Married & $\begin{array}{c}-0.096^{\star \star \star} \\
(0.020)\end{array}$ & $\begin{array}{c}0.014 \\
(0.012)\end{array}$ & $\begin{array}{l}0.039^{* *} \\
(0.019)\end{array}$ & $\begin{array}{l}0.043^{\star} \\
(0.023)\end{array}$ \\
\hline Education level: secondary & $\begin{array}{l}-0.008 \\
(0.017)\end{array}$ & $\begin{array}{c}-0.039^{* * *} \\
(0.015)\end{array}$ & $\begin{array}{l}-0.019 \\
(0.018)\end{array}$ & $\begin{array}{c}0.065^{\star * *} \\
(0.021)\end{array}$ \\
\hline Education level: tertiary & $\begin{array}{c}-0.091^{* * *} \\
(0.017)\end{array}$ & $\begin{array}{c}-0.042^{* * *} \\
(0.014)\end{array}$ & $\begin{array}{c}-0.129^{* \star *} \\
(0.019)\end{array}$ & $\begin{array}{c}0.262^{* * *} \\
(0.026)\end{array}$ \\
\hline Household size & $\begin{array}{c}0.010^{* * *} \\
(0.003)\end{array}$ & $\begin{array}{l}-0.001 \\
(0.003)\end{array}$ & $\begin{array}{l}-0.005 \\
(0.003)\end{array}$ & $\begin{array}{l}-0.004 \\
(0.005)\end{array}$ \\
\hline No. of children $(<15)$ & $\begin{array}{l}-0.011^{*} \\
(0.006)\end{array}$ & $\begin{array}{c}0.006 \\
(0.004)\end{array}$ & $\begin{array}{l}0.016^{* * *} \\
(0.006)\end{array}$ & $\begin{array}{l}-0.011 \\
(0.007)\end{array}$ \\
\hline No. of elderly (>62) & $\begin{array}{c}0.002 \\
(0.010)\end{array}$ & $\begin{array}{c}0.014 \\
(0.010)\end{array}$ & $\begin{array}{l}-0.006 \\
(0.013)\end{array}$ & $\begin{array}{l}-0.009 \\
(0.014)\end{array}$ \\
\hline Rural location & $\begin{array}{c}-0.054^{\star *} \\
(0.025)\end{array}$ & $\begin{array}{l}0.069^{* \star *} \\
(0.019)\end{array}$ & $\begin{array}{l}-0.030 \\
(0.028)\end{array}$ & $\begin{array}{c}0.015 \\
(0.032)\end{array}$ \\
\hline Regional controls & Yes & Yes & Yes & Yes \\
\hline $\begin{array}{l}\text { Observations } \\
\text { Wald Chi-squared } \\
\text { Log pseudo likelihood }\end{array}$ & \multicolumn{4}{|c|}{$\begin{array}{c}5,909 \\
732.23 \\
-6750.63 \\
\end{array}$} \\
\hline
\end{tabular}

Robust standard errors in parentheses, adjusted for 267 clusters at panel sampling unit level. ${ }^{* * *} p<0.01,{ }^{* *} p<0.05,{ }^{*} p<0.1$ 
Table 3: Control function approach - amount of remittances

\begin{tabular}{|c|c|c|c|c|c|}
\hline & OLS & & \multicolumn{2}{|c|}{ Marginal effect after mprobit } & \multirow[b]{2}{*}{$\begin{array}{c}\text { Wage } \\
\text { employment }\end{array}$} \\
\hline & & $\begin{array}{c}\text { Not } \\
\text { working }\end{array}$ & $\begin{array}{c}\text { Working on } \\
\text { HH farm }\end{array}$ & $\begin{array}{l}\text { Working in } \\
\mathrm{HH} \text { business }\end{array}$ & \\
\hline Log of remittances & & $\begin{array}{c}-0.001 \\
(0.018)\end{array}$ & $\begin{array}{c}0.013 \\
(0.016)\end{array}$ & $\begin{array}{l}0.040^{* *} \\
(0.019)\end{array}$ & $\begin{array}{c}-0.052^{* *} \\
(0.021)\end{array}$ \\
\hline Age & $\begin{array}{c}-0.103^{\star * *} \\
(0.025)\end{array}$ & $\begin{array}{c}-0.017^{\star * *} \\
(0.004)\end{array}$ & $\begin{array}{l}-0.003 \\
(0.003)\end{array}$ & $\begin{array}{l}0.011^{* *} \\
(0.005)\end{array}$ & $\begin{array}{l}0.009 \\
(0.006)\end{array}$ \\
\hline Age squared x 100 & $\begin{array}{c}0.143^{\star * *} \\
(0.031)\end{array}$ & $\begin{array}{c}0.016^{\star * *} \\
(0.005)\end{array}$ & $\begin{array}{l}0.005 \\
(0.004)\end{array}$ & $\begin{array}{c}-0.015^{\star \star} \\
(0.006)\end{array}$ & $\begin{array}{l}-0.006 \\
(0.007)\end{array}$ \\
\hline Married & $\begin{array}{c}0.010 \\
(0.121)\end{array}$ & $\begin{array}{c}-0.096^{* * *} \\
(0.020)\end{array}$ & $\begin{array}{c}0.015 \\
(0.012)\end{array}$ & $\begin{array}{l}0.040^{\star *} \\
(0.019)\end{array}$ & $\begin{array}{l}0.041^{*} \\
(0.023)\end{array}$ \\
\hline Education level: secondary & $\begin{array}{l}-0.030 \\
(0.121)\end{array}$ & $\begin{array}{l}-0.009 \\
(0.017)\end{array}$ & $\begin{array}{c}-0.038^{* * *} \\
(0.015)\end{array}$ & $\begin{array}{l}-0.017 \\
(0.018)\end{array}$ & $\begin{array}{c}0.064^{* * *} \\
(0.021)\end{array}$ \\
\hline Education level: tertiary & $\begin{array}{c}-0.353^{* *} \\
(0.152)\end{array}$ & $\begin{array}{c}-0.092^{* * *} \\
(0.018)\end{array}$ & $\begin{array}{c}-0.038^{\star \star *} \\
(0.014)\end{array}$ & $\begin{array}{c}-0.117^{\star \star *} \\
(0.021)\end{array}$ & $\begin{array}{c}0.247^{* \star *} \\
(0.027)\end{array}$ \\
\hline Household size & $\begin{array}{c}0.027 \\
(0.026)\end{array}$ & $\begin{array}{c}0.012^{* * *} \\
(0.004)\end{array}$ & $\begin{array}{l}-0.001 \\
(0.003)\end{array}$ & $\begin{array}{c}-0.008^{* *} \\
(0.004)\end{array}$ & $\begin{array}{l}-0.002 \\
(0.005)\end{array}$ \\
\hline No. of children $(<15)$ & $\begin{array}{l}-0.023 \\
(0.043)\end{array}$ & $\begin{array}{c}-0.014^{\star *} \\
(0.006)\end{array}$ & $\begin{array}{c}0.006 \\
(0.005)\end{array}$ & $\begin{array}{c}0.019^{* * *} \\
(0.006)\end{array}$ & $\begin{array}{l}-0.011 \\
(0.008)\end{array}$ \\
\hline No. of elderly (>62) & $\begin{array}{c}-0.292^{* * *} \\
(0.084)\end{array}$ & $\begin{array}{l}-0.001 \\
(0.012)\end{array}$ & $\begin{array}{c}0.017 \\
(0.011)\end{array}$ & $\begin{array}{l}0.004 \\
(0.015)\end{array}$ & $\begin{array}{l}-0.020 \\
(0.015)\end{array}$ \\
\hline Rural location & $\begin{array}{c}0.247 \\
(0.177)\end{array}$ & $\begin{array}{c}-0.052^{\star *} \\
(0.026)\end{array}$ & $\begin{array}{c}0.067^{\star \star *} \\
(0.019)\end{array}$ & $\begin{array}{l}-0.040 \\
(0.029)\end{array}$ & $\begin{array}{c}0.025 \\
(0.031)\end{array}$ \\
\hline $\begin{array}{l}\text { Regional controls } \\
\text { No. of migrants in community }\end{array}$ & $\begin{array}{c}\text { Yes } \\
0.275^{\star \star \star} \\
(0.046)\end{array}$ & Yes & Yes & Yes & Yes \\
\hline Ethnicity: Tajik & $\begin{array}{l}0.312^{\star \star \star} \\
(0.113)\end{array}$ & & & & \\
\hline Constant & $\begin{array}{l}1.932^{\star * *} \\
(0.426)\end{array}$ & & & & \\
\hline OLS residual & & $\begin{array}{c}0.007 \\
(0.018) \\
\end{array}$ & $\begin{array}{l}-0.012 \\
(0.016) \\
\end{array}$ & $\begin{array}{c}-0.038^{\star *} \\
(0.019) \\
\end{array}$ & $\begin{array}{l}0.043^{* *} \\
(0.021) \\
\end{array}$ \\
\hline $\begin{array}{l}\text { Observations } \\
\text { R-squared }\end{array}$ & $\begin{array}{l}5,909 \\
0.065\end{array}$ & & & 909 & \\
\hline $\begin{array}{l}\text { Wald Chi-squared } \\
\text { Log pseudo likelihood }\end{array}$ & & & & $\begin{array}{l}.45 \\
4.64\end{array}$ & \\
\hline
\end{tabular}

Robust standard errors in parentheses, adjusted for 267 clusters at panel sampling unit level.

${ }^{* * *} \mathrm{p}<0.01,{ }^{* *} \mathrm{p}<0.05,{ }^{*} \mathrm{p}<0.1$ 
Table 4: Multinomial probit marginal effects - number of migrants in household

\begin{tabular}{|c|c|c|c|c|}
\hline & Not working & $\begin{array}{c}\text { Working on } \\
\mathrm{HH} \text { farm }\end{array}$ & $\begin{array}{l}\text { Working in } \\
\mathrm{HH} \text { business }\end{array}$ & $\begin{array}{c}\text { Wage } \\
\text { employment }\end{array}$ \\
\hline No. of migrants in household & $\begin{array}{c}0.034^{\star * \star} \\
(0.011)\end{array}$ & $\begin{array}{c}0.019^{*} \\
(0.010)\end{array}$ & $\begin{array}{c}0.003 \\
(0.013)\end{array}$ & $\begin{array}{c}-0.056^{* * *} \\
(0.017)\end{array}$ \\
\hline Age & $\begin{array}{c}-0.016^{* * *} \\
(0.004)\end{array}$ & $\begin{array}{l}-0.004 \\
(0.003)\end{array}$ & $\begin{array}{l}0.007^{*} \\
(0.004)\end{array}$ & $\begin{array}{l}0.012^{* *} \\
(0.005)\end{array}$ \\
\hline Age squared x 100 & $\begin{array}{c}0.015^{\star \star *} \\
(0.005)\end{array}$ & $\begin{array}{l}0.006^{\star} \\
(0.003)\end{array}$ & $\begin{array}{l}-0.010^{*} \\
(0.006)\end{array}$ & $\begin{array}{l}-0.011^{*} \\
(0.006)\end{array}$ \\
\hline Married & $\begin{array}{c}-0.097^{\star \star \star} \\
(0.020)\end{array}$ & $\begin{array}{c}0.013 \\
(0.012)\end{array}$ & $\begin{array}{l}0.040^{* *} \\
(0.019)\end{array}$ & $\begin{array}{l}0.044^{\star} \\
(0.023)\end{array}$ \\
\hline Education level: secondary & $\begin{array}{l}-0.007 \\
(0.018)\end{array}$ & $\begin{array}{c}-0.038^{* *} \\
(0.015)\end{array}$ & $\begin{array}{l}-0.019 \\
(0.018)\end{array}$ & $\begin{array}{c}0.064^{* * *} \\
(0.021)\end{array}$ \\
\hline Education level: tertiary & $\begin{array}{c}-0.090^{* * *} \\
(0.017)\end{array}$ & $\begin{array}{c}-0.042^{* * *} \\
(0.014)\end{array}$ & $\begin{array}{c}-0.129^{* * *} \\
(0.019)\end{array}$ & $\begin{array}{c}0.261^{* * *} \\
(0.026)\end{array}$ \\
\hline Household size & $\begin{array}{c}0.010^{* * *} \\
(0.004)\end{array}$ & $\begin{array}{l}-0.001 \\
(0.003)\end{array}$ & $\begin{array}{l}-0.005 \\
(0.003)\end{array}$ & $\begin{array}{l}-0.004 \\
(0.005)\end{array}$ \\
\hline No. of children $(<15)$ & $\begin{array}{l}-0.011^{*} \\
(0.006)\end{array}$ & $\begin{array}{c}0.006 \\
(0.004)\end{array}$ & $\begin{array}{c}0.016^{* * *} \\
(0.006)\end{array}$ & $\begin{array}{l}-0.011 \\
(0.007)\end{array}$ \\
\hline No. of elderly (>62) & $\begin{array}{c}0.001 \\
(0.010)\end{array}$ & $\begin{array}{c}0.014 \\
(0.010)\end{array}$ & $\begin{array}{l}-0.007 \\
(0.013)\end{array}$ & $\begin{array}{l}-0.008 \\
(0.014)\end{array}$ \\
\hline Rural location & $\begin{array}{c}-0.055^{\star *} \\
(0.025)\end{array}$ & $\begin{array}{c}0.068^{* \star *} \\
(0.019)\end{array}$ & $\begin{array}{l}-0.029 \\
(0.028)\end{array}$ & $\begin{array}{c}0.016 \\
(0.032)\end{array}$ \\
\hline Regional controls & Yes & Yes & Yes & Yes \\
\hline $\begin{array}{l}\text { Observations } \\
\text { Wald Chi-squared } \\
\text { Log pseudo likelihood }\end{array}$ & \multicolumn{4}{|c|}{$\begin{array}{c}5,909 \\
726.19 \\
-6747.62\end{array}$} \\
\hline
\end{tabular}

Robust standard errors in parentheses, adjusted for 267 clusters at panel sampling unit level. ${ }^{* * *} p<0.01,{ }^{* *} p<0.05,{ }^{*} p<0.1$ 
Table 5: Control function approach - number of migrants in household

\begin{tabular}{|c|c|c|c|c|c|}
\hline & \multirow[t]{2}{*}{ GLM } & \multicolumn{4}{|c|}{ Marginal effect after mprobit } \\
\hline & & $\begin{array}{c}\text { Not } \\
\text { working }\end{array}$ & $\begin{array}{c}\text { Working on } \\
\text { HH farm }\end{array}$ & $\begin{array}{l}\text { Working in } \\
\mathrm{HH} \text { business }\end{array}$ & $\begin{array}{c}\text { Wage } \\
\text { employment }\end{array}$ \\
\hline No. of migrants in household & & $\begin{array}{l}0.016 \\
(0.041)\end{array}$ & $\begin{array}{l}0.088^{* *} \\
(0.039)\end{array}$ & $\begin{array}{l}0.094^{* *} \\
(0.045)\end{array}$ & $\begin{array}{c}-0.198^{\star * \star} \\
(0.061)\end{array}$ \\
\hline Age & $\begin{array}{c}-0.110^{\star * *} \\
(0.019)\end{array}$ & $\begin{array}{c}-0.017^{\star \star \star *} \\
(0.004)\end{array}$ & $\begin{array}{l}-0.002 \\
(0.003)\end{array}$ & $\begin{array}{l}0.010^{\star *} \\
(0.004)\end{array}$ & $\begin{array}{l}0.009 \\
(0.005)\end{array}$ \\
\hline Age squared x 100 & $\begin{array}{l}0.154^{* * *} \\
(0.023)\end{array}$ & $\begin{array}{l}0.016^{* * *} \\
(0.005)\end{array}$ & $\begin{array}{l}0.003 \\
(0.004)\end{array}$ & $\begin{array}{l}-0.013^{* *} \\
(0.006)\end{array}$ & $\begin{array}{l}-0.006 \\
(0.007)\end{array}$ \\
\hline Married & $\begin{array}{c}0.030 \\
(0.132)\end{array}$ & $\begin{array}{c}-0.097^{\star \star \star} \\
(0.020)\end{array}$ & $\begin{array}{c}0.013 \\
(0.012)\end{array}$ & $\begin{array}{l}0.038^{\star *} \\
(0.019)\end{array}$ & $\begin{array}{l}0.045^{*} \\
(0.023)\end{array}$ \\
\hline Education level: secondary & $\begin{array}{l}-0.121 \\
(0.092)\end{array}$ & $\begin{array}{l}-0.008 \\
(0.018)\end{array}$ & $\begin{array}{l}-0.037^{* *} \\
(0.015)\end{array}$ & $\begin{array}{l}-0.017 \\
(0.018)\end{array}$ & $\begin{array}{l}0.062^{* * *} \\
(0.021)\end{array}$ \\
\hline Education level: tertiary & $\begin{array}{c}-0.479^{* * *} \\
(0.148)\end{array}$ & $\begin{array}{c}-0.091^{* * *} \\
(0.018)\end{array}$ & $\begin{array}{c}-0.036^{\star *} \\
(0.015)\end{array}$ & $\begin{array}{c}-0.123^{* \star *} \\
(0.020)\end{array}$ & $\begin{array}{c}0.250^{\star \star *} \\
(0.027)\end{array}$ \\
\hline Household size & $\begin{array}{c}0.045 \\
(0.027)\end{array}$ & $\begin{array}{l}0.010^{* * *} \\
(0.004)\end{array}$ & $\begin{array}{l}-0.002 \\
(0.003)\end{array}$ & $\begin{array}{l}-0.006^{\star} \\
(0.003)\end{array}$ & $\begin{array}{l}-0.002 \\
(0.005)\end{array}$ \\
\hline No. of children $(<15)$ & $\begin{array}{l}-0.036 \\
(0.045)\end{array}$ & $\begin{array}{l}-0.011^{*} \\
(0.006)\end{array}$ & $\begin{array}{l}0.006 \\
(0.004)\end{array}$ & $\begin{array}{l}0.016^{* * *} \\
(0.006)\end{array}$ & $\begin{array}{l}-0.012 \\
(0.007)\end{array}$ \\
\hline No. of elderly (>62) & $\begin{array}{c}-0.196^{\star *} \\
(0.096)\end{array}$ & $\begin{array}{c}0.001 \\
(0.011)\end{array}$ & $\begin{array}{c}0.016 \\
(0.010)\end{array}$ & $\begin{array}{l}-0.004 \\
(0.013)\end{array}$ & $\begin{array}{l}-0.013 \\
(0.014)\end{array}$ \\
\hline Rural location & $\begin{array}{l}0.382^{*} \\
(0.218)\end{array}$ & $\begin{array}{l}-0.054^{* *} \\
(0.026)\end{array}$ & $\begin{array}{l}0.065^{\star * *} \\
(0.020)\end{array}$ & $\begin{array}{l}-0.037 \\
(0.028)\end{array}$ & $\begin{array}{l}0.025 \\
(0.032)\end{array}$ \\
\hline $\begin{array}{l}\text { Regional controls } \\
\text { No. of migrants in community }\end{array}$ & $\begin{array}{c}\text { Yes } \\
0.208^{\star * *} \\
(0.027)\end{array}$ & Yes & Yes & Yes & Yes \\
\hline Ethnicity: Tajik & $\begin{array}{l}0.090 \\
(0.162)\end{array}$ & & & & \\
\hline Constant & $\begin{array}{l}-0.744^{*} \\
(0.404)\end{array}$ & & & & \\
\hline GLM deviance residual & & $\begin{array}{c}0.014 \\
(0.027)\end{array}$ & $\begin{array}{l}-0.048^{*} \\
(0.026)\end{array}$ & $\begin{array}{c}-0.060^{* *} \\
(0.029)\end{array}$ & $\begin{array}{l}0.094^{* *} \\
(0.040)\end{array}$ \\
\hline $\begin{array}{l}\text { Observations } \\
\text { Wald Chi-squared } \\
\text { Log pseudo likelihood }\end{array}$ & -2863.63 & & & $\begin{array}{l}09 \\
.63 \\
9.95\end{array}$ & \\
\hline
\end{tabular}

Robust standard errors in parentheses, adjusted for 267 clusters at panel sampling unit level.

${ }^{* * *} p<0.01,{ }^{* *} p<0.05,{ }^{*} p<0.1$ 
Table 6: Decomposition of differences in predicted probabilities of occupation choice between men and women

\begin{tabular}{|c|c|c|c|c|c|c|c|c|c|}
\hline & \multicolumn{2}{|c|}{ Predicted probabilities } & \multicolumn{2}{|c|}{ Counterfactuals } & \multirow[t]{2}{*}{$\begin{array}{c}\text { Total } \\
\text { difference }\end{array}$} & \multirow[t]{2}{*}{$\begin{array}{c}\text { Endowment } \\
\text { effect }\end{array}$} & \multirow[t]{2}{*}{$\begin{array}{c}\text { Treatment } \\
\text { effect }\end{array}$} & \multirow[t]{2}{*}{$\begin{array}{c}\text { Endowment } \\
\text { effect }\end{array}$} & \multirow[t]{2}{*}{$\begin{array}{l}\text { Treatment } \\
\text { effect }\end{array}$} \\
\hline & $\begin{array}{c}\text { men } \\
\text { coefficients; } \\
\text { men } \\
\text { characteristics }\end{array}$ & $\begin{array}{c}\text { women } \\
\text { coefficients; } \\
\text { women } \\
\text { characteristics }\end{array}$ & $\begin{array}{c}\text { women } \\
\text { coefficients; } \\
\text { men } \\
\text { characteristics }\end{array}$ & $\begin{array}{c}\text { men } \\
\text { coefficients; } \\
\text { women } \\
\text { characteristics }\end{array}$ & & & & & \\
\hline & Eqn. (8) & Eqn. (9) & Eqn. (10) & Eqn. (11) & $(8)-(9)$ & $(8)-(11)$ & $(11)-(9)$ & $(10)-(9)$ & $(8)-(10)$ \\
\hline $\begin{array}{l}\text { Occupation: not } \\
\text { working }\end{array}$ & 0.178 & 0.109 & 0.093 & 0.213 & 0.069 & -0.035 & 0.104 & -0.017 & 0.086 \\
\hline $\begin{array}{l}\text { Occupation: } \\
\text { working on } \mathrm{HH} \\
\text { farm }\end{array}$ & 0.118 & 0.196 & 0.196 & 0.118 & -0.079 & -0.001 & -0.078 & -0.001 & -0.078 \\
\hline $\begin{array}{l}\text { Occupation: } \\
\text { working in } \mathrm{HH} \\
\text { business }\end{array}$ & 0.202 & 0.207 & 0.214 & 0.199 & -0.005 & 0.003 & -0.008 & 0.006 & -0.011 \\
\hline $\begin{array}{l}\text { Occupation: wage } \\
\text { employment }\end{array}$ & 0.502 & 0.487 & 0.498 & 0.470 & 0.015 & 0.032 & -0.017 & 0.011 & 0.004 \\
\hline
\end{tabular}

Note: Predicted probabilities based on control function approach with log of remittances as covariate. 